\title{
Petrobacter succinatimandens gen. nov., sp. nov., a moderately thermophilic, nitrate-reducing bacterium isolated from an Australian oil well
}

Correspondence Bernard Ollivier ollivier@esil.univ-mrs.fr

\author{
Monica Bonilla Salinas, ${ }^{1}$ Marie-Laure Fardeau, ${ }^{1}$ Jean-Luc Cayol, ${ }^{1}$ \\ Laurence Casalot, ${ }^{1}$ Bharat K. C. Patel, ${ }^{2}$ Pierre Thomas, ${ }^{1}$ \\ Jean-Louis Garcia ${ }^{1}$ and Bernard Ollivier ${ }^{1}$ \\ ${ }^{1}$ IRD, UR 101 Extrêmophiles, IFR-BAIM, Universités de Provence et de la Méditerranée, ESIL, \\ Marseille, France \\ ${ }^{2}$ School of Biomolecular and Biomedical Sciences, Griffith University, Brisbane, Australia
}

Petroleum reservoirs harbour a rich and diverse community of micro-organisms including (i) fermentative, (ii) sulfate-, thiosulfate- and sulfur-reducing, (iii) nitratereducing, (iv) methanogenic and (v) metal-respiring micro-organisms (Magot et al., 2000). Among these micro-organisms, heterotrophic together with hydrogenotrophic micro-organisms (e.g. methanogens and sulfatereducing bacteria) are considered as common inhabitants of oilfield environments (Ivanov et al., 1983; Fardeau et al., 1993, 1997, 2000; Grassia et al., 1996; Magot et al., 2000; Mueller \& Nielsen, 1996; Nilsen et al., 1996; Ollivier et al., 1998). Despite the fact that organic acids are known to occur in oil reservoirs (Rees et al., 1997), a great deal of attention has been paid by microbiologists to heterotrophic micro-organisms using carbohydrates in these environments (Fardeau et al., 1993, 1997, 2000; Magot et al., 2000); therefore, little information is available on the isolation of heterotrophic non-sulfate-reducing bacteria that use organic acids (e.g. fumarate, succinate, etc.)

Published online ahead of print on 13 October 2003 as DOI 10.1099/ ijs.0.02732-0.

The GenBank/EMBL/DDBJ accession number for the 16S rRNA gene sequence of Petrobacter succinatimandens $4 \mathrm{BON}^{\top}$ is $\mathrm{AY} 219713$.

A transmission electron micrograph of strain $4 \mathrm{BON}^{\top}$ and a graph showing the effect of temperature on the growth of strain $4 B O N^{\top}$ cultivated on succinate are available from IJSEM Online. aerobically or anaerobically. The only organic-acid-using micro-organisms isolated from oilfield ecosystems, unable to use sulfate as terminal electron acceptor, include members of the genera Marinobacter (Huu et al., 1999), Deferribacter (Greene et al., 1997), Denitrovibrio (Myhr \& Torsvik, 2000) and Anaerobaculum (Rees et al., 1997).

Here, we describe a novel moderately thermophilic, organicacid-using, nitrate-reducing bacterium (strain $4 \mathrm{BON}^{\mathrm{T}}$ ), belonging to the $\beta$-Proteobacteria, isolated from a nonwater-flooded Australian terrestrial oil reservoir. It presented significant phenotypic, genotypic and phylogenetic differences when compared with members of the $\beta$ Proteobacteria, which led to the proposal of it being assigned to a novel genus, Petrobacter, as the type and sole species, Petrobacter succinatimandens.

The oil sample used in this study was collected from the Riverslea oilfield in the Bowen-Surat basin of Eastern Australia (Queensland). The sample was designated OCA5 and was stored at $4{ }^{\circ} \mathrm{C}$ until used. Enrichment was performed in a medium prepared anaerobically (Fardeau et al., 2000) containing ( $\left(^{-1}\right.$ distilled water) $0 \cdot 3 \mathrm{~g} \mathrm{~K}_{2} \mathrm{HPO}_{4}, 0 \cdot 3 \mathrm{~g}$ $\mathrm{KH}_{2} \mathrm{PO}_{4}, 0 \cdot 2 \mathrm{~g} \mathrm{MgCl}_{2} \cdot 6 \mathrm{H}_{2} \mathrm{O}, 0 \cdot 1 \mathrm{~g} \mathrm{CaCl}_{2} .2 \mathrm{H}_{2} \mathrm{O}, 0 \cdot 1 \mathrm{~g} \mathrm{KCl}$, $1 \mathrm{~g} \mathrm{NaCl}, 1 \mathrm{~g} \mathrm{NH} \mathrm{Nl}_{4} \mathrm{Cl}, 10 \mathrm{mM} \mathrm{CH} \mathrm{CH}_{3} \mathrm{COONa}, 1 \mathrm{~g}$ yeast extract (Difco Laboratories) and $10 \mathrm{ml}$ of the trace mineral solution of Balch et al. (1979). The $\mathrm{pH}$ was adjusted to $7 \cdot 0$ with $10 \mathrm{M} \mathrm{KOH}$. The vessels were autoclaved for $45 \mathrm{~min}$ 
at $110{ }^{\circ} \mathrm{C}$ and, prior to inoculation, $10 \mathrm{mM} \mathrm{KNO}_{3}$ and $0.5 \%$ $(\mathrm{v} / \mathrm{v})$ of the vitamin solution of Balch et al. (1979) were added from sterile stock solutions. $\mathrm{A}_{2} / \mathrm{CO}_{2}$ mixture (2 bars) was added in the gas phase. For enrichment, a $2 \mathrm{ml}$ oil-well water sample was inoculated into $20 \mathrm{ml}$ of medium and incubated at $50{ }^{\circ} \mathrm{C}$ without agitation. Three enrichment series were performed in the same medium before isolation. Strains were isolated by repeated use of the Hungate roll-tube technique (Hungate, 1969), with medium solidified with $2 \%$ agar noble (Difco). The basal medium, used for characterization of $\mathrm{pH}$, temperature and $\mathrm{NaCl}$ ranges for growth of the isolates, was similar to the enrichment medium supplemented with $20 \mathrm{mM}$ sodium succinate. The culture medium was adjusted to different $\mathrm{pH}$ values by injecting $\mathrm{NaHCO}_{3}$ from $10 \%(\mathrm{w} / \mathrm{v})$ sterile anaerobic stock solutions. For studies on $\mathrm{NaCl}$ requirements, $\mathrm{NaCl}$ was weighed directly in the tubes prior to dispensing the medium. Substrates were tested in aerobiosis (nitrogen was replaced by air in the gas phase) and anaerobiosis (in the presence and in the absence of nitrate as terminal electron acceptor) in basal medium at a final concentration of $20 \mathrm{mM}$. As a test for electron acceptors, sodium thiosulfate $(20 \mathrm{mM})$, sodium sulfate $(20 \mathrm{mM})$, sodium sulfite $(2 \mathrm{mM})$, elemental sulfur $(1 \%, \mathrm{w} / \mathrm{v})$, potassium nitrate $(10 \mathrm{mM})$ and potassium nitrite $(2 \mathrm{mM})$ were added to the medium. The use of electron acceptors was evaluated by measuring the optical density at $580 \mathrm{~nm}$ and by measuring $\mathrm{H}_{2} \mathrm{~S}$, ammonium, nitrite or nitrous oxide production.

Sulfide was determined photometrically as colloidal CuS by using the method of Cord-Ruwisch (1985). Nitrite was detected by the colorimetric method of Griess-Illosvay (Knapp \& Clark, 1984) and by the Quantofix test (MachereyNagel). Nitrous oxide was measured by gas chromatography (Fardeau et al., 1993). Organic compounds were determined as described previously (Fardeau et al., 1997). Morphological characteristics of isolates were observed with an optiphot (Nikon) phase microscope. Electron microscopy studies were performed as described by Koussémon et al. (2001).

The $\mathrm{G}+\mathrm{C}$ content of the DNA of strain $4 \mathrm{BON}^{\mathrm{T}}$ was determined at the DSMZ (Deutsche Sammlung von Mikroorganismen und Zellkulturen, Braunschweig, Germany) by using HPLC as described by Mesbah et al. (1989). Non-methylated lambda DNA (Sigma) was used as the standard. The 16S rRNA gene of the isolate was amplified as described previously (Miranda-Tello et al., 2003). The PCR products were purified by using a NucleoSpin Extract kit (Macherey Nagel) and were cloned into the vector PGEM-T-easy (Promega). Plasmids containing the insert were purified using the Wizard Plus SV Minipreps DNA Purification System (Promega), according to the manufacturer's protocol. Sequencing was carried out by Genome Express (Grenoble, France). The new sequence was aligned to a full-length $16 \mathrm{~S}$ rDNA consensus sequence, assembled and checked manually for accuracy using the alignment editor BIOEDIT v5.0.9 (Hall, 1999). The 16S rRNA gene sequence of strain $4 \mathrm{BON}^{\mathrm{T}}$ was compared with other sequences in the GenBank database (Benson et al., 1999) and RDP (Maidak et al., 2001), using BLAST (Altschul et al., 1997) to identify its closest relatives. The sequences of the closest relatives were retrieved and, together with the 16S rRNA gene sequence of strain $4 \mathrm{BON}^{\mathrm{T}}$, were subjected to a phylogenetic analysis. Positions of sequence and alignment ambiguity were omitted from the analysis and the pair-wise evolutionary distances based on 1374 unambiguous nucleotides were computed by using the method of Jukes \& Cantor (1969). A dendrogram was constructed using the neighbour-joining method (Saitou \& Nei, 1987). Confidence in the tree topology was determined by using 100 bootstrapped trees (Felsenstein, 1993). The accession numbers for the $16 \mathrm{~S}$ rDNA sequences of the reference organisms are included in Fig. 1.

Enrichment cultures were positive for growth after 10 days incubation at $37^{\circ} \mathrm{C}$ or 4 days incubation at $50^{\circ} \mathrm{C}$. Microscopic examination of the cultures revealed the presence of motile, rod-shaped bacteria. Round, yellowish, smooth colonies (1-2 $\mathrm{mm}$ in diameter) developed on roll tubes after 10 days incubation at both temperatures. Single colonies were picked and streaking was repeated three times before cultures were considered pure. Three strains, similar in morphology, were isolated. Strain $2 \mathrm{BON}$ was isolated at $37^{\circ} \mathrm{C}$, whereas strains $3 \mathrm{BON}$ and $4 \mathrm{BON}^{\mathrm{T}}$ were isolated at $50{ }^{\circ} \mathrm{C}$. As all these strains had identical $16 \mathrm{~S}$ rDNA sequences, and since strain $2 \mathrm{BON}$ also grew at $50{ }^{\circ} \mathrm{C}$, strain $4 \mathrm{BON}^{\mathrm{T}}$ was used for further characterization. Cells of strain $4 \mathrm{BON}^{\mathrm{T}}$ were straight rods that were $0 \cdot 3-$ $0 \cdot 4 \times 2 \mu \mathrm{m}$ in size, motile by means of a polar flagellum (see image available in IJSEM Online) and occurred singly or in pairs. No spore formation was detected. Cell ultrathin sections showed a thin cell wall (data not shown). Strain $4 \mathrm{BON}^{\mathrm{T}}$ grew at temperatures ranging from 35 to $60{ }^{\circ} \mathrm{C}$, and optimum growth was obtained at $55^{\circ} \mathrm{C}(\mathrm{pH} 7)$ (see graph available in IJSEM Online). Growth occurred at initial $\mathrm{pH}$ values of between 5.5 and 8.0 at $55^{\circ} \mathrm{C}$, and the optimum $\mathrm{pH}$ was 6.9 . The strain grew in the presence of $\mathrm{NaCl}$ concentrations ranging from 0 to $3 \%$, and the optimum $\mathrm{NaCl}$ concentration was $0.5 \%$ at $\mathrm{pH} 7$ and $55^{\circ} \mathrm{C}$. Growth was weak in the absence of yeast extract. Strain $4 \mathrm{BON}^{\mathrm{T}}$ grew with oxygen or nitrate as terminal electron acceptors, using fumarate, pyruvate, formate, ethanol, succinate and yeast extract as energy sources. The following compounds were not used in aerobiosis and in the presence of nitrate as terminal electron acceptor: acetate, butyrate, propionate, valerate, isovalerate, lactate, adipate, alanine, L-glutamate, proline, serine, valine, fructose, glucose, lactose, maltose, ribose, xylose, vanillate, benzoate, 4-hydroxybenzoate, 3-methylbenzoate, phenylacetate, 4aminobenzoate, benzaldehyde. Nitrate was reduced to nitrous oxide. Nitrite was an intermediary product of nitrate reduction.

The in situ physicochemical conditions, together with the 


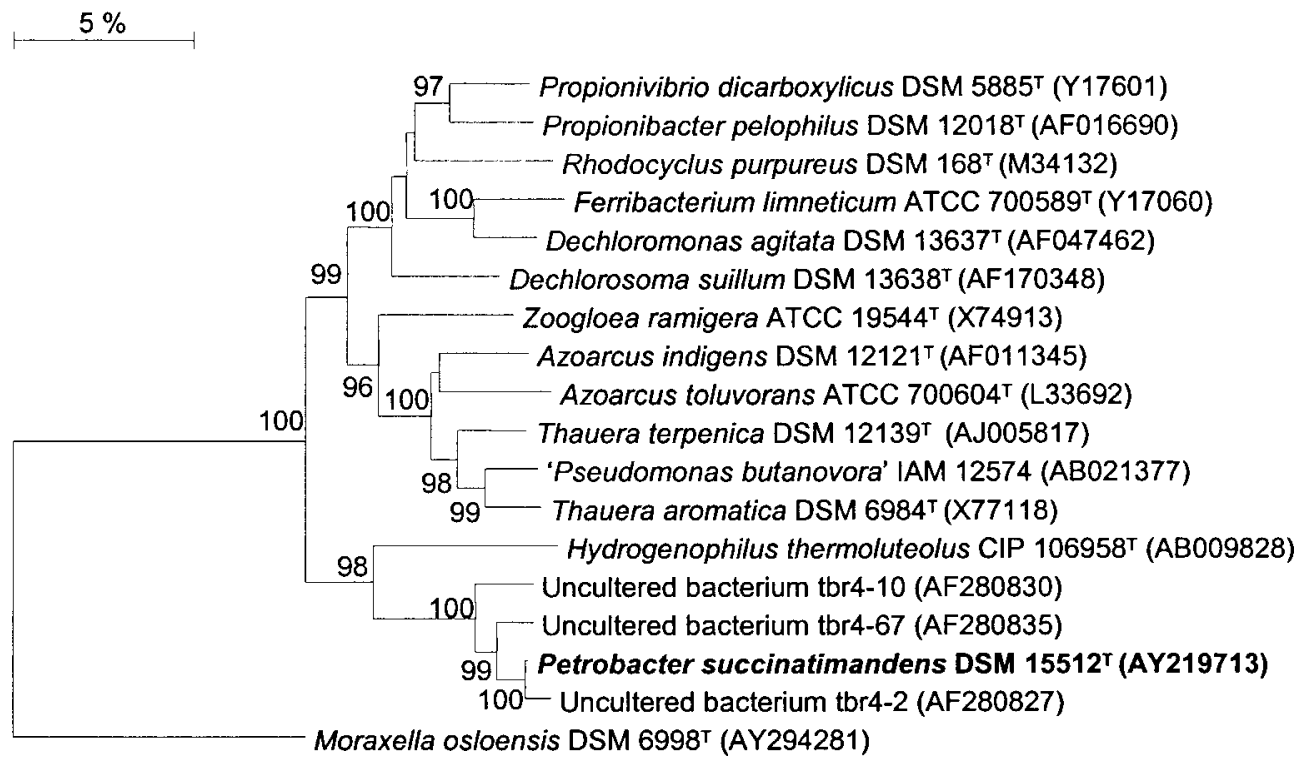

Fig. 1. Phylogenetic tree based on $16 \mathrm{~S}$ rDNA sequences, constructed by the neighbour-joining method, showing the position of strain $4 \mathrm{BON}^{\top}$ among members of the $\beta$-Proteobacteria. Sequence accession numbers are given in parentheses. Numbers on the branches are confidence limits (expressed as percentages) estimated by a bootstrap analysis performed using 100 replications. Confidence limits less than $80 \%$ are not shown. Bar, 5 nt substitutions per 100 nt.

presence of phenotypically and phylogenetically closely related anaerobes in oilfields, suggest that oil reservoirs are mainly anaerobic ecosystems (Magot et al., 2000). However, the accidental introduction of oxygen into oil reservoirs cannot be excluded due to water-flooding during oil extraction. This might partly explain the occurrence of aerobic to microaerophilic bacteria in oilfield ecosystems (Gevertz et al., 2000; Voordouw et al., 1996; Telang et al., 1997). Among these micro-organisms, hydrogen-oxidizers, using nitrate as their terminal electron acceptor, have been isolated and characterized (Gevertz et al., 2000). Attempts to isolate phenotypically similar micro-organisms from the Australian oil reservoirs that we studied were unsuccessful. Despite the presence of hydrogen as energy source in the enrichment medium that we used, our microbiological studies only led to the isolation of heterotrophic bacteria that used organic acids, aerobically or anaerobically, but not hydrogen. Isolation of these bacteria was only allowed by the presence of yeast extract in the original enrichment medium. The subsequent isolation on other substrates of organic-acid-users originating from oilfield ecosystems has already been reported (Davydova-Charakhch'yan et al., 1992; Rees et al., 1997). Strain $4 \mathrm{BON}^{\mathrm{T}}$, isolated from an Australian oil reservoir in Queensland, was further characterized and was shown to oxidize a limited range of organic acids (pyruvate, fumarate, succinate) together with ethanol. Despite the fact that strain $4 \mathrm{BON}^{\mathrm{T}}$ is an aerobic, nitrate-reducing bacterium, it differed phylogenetically from strains CVO and FWKO B, isolated from Canadian oilfields, as they both belong to the epsilon subdivision of the Proteobacteria. In contrast, strain $4 \mathrm{BON}^{\mathrm{T}}$ belongs to the beta subdivision of the Proteobacteria, as indicated by the phylogenetic tree shown in Fig. 1, and it oxidizes neither elemental sulfur nor thiosulfate. Strain $4 \mathrm{BON}^{\mathrm{T}}$ also differed significantly from other nitrate-reducing bacteria isolated from oil reservoirs: Deferribacter thermophilus is a strict anaerobe which is most closely related to Flexistipes sinusarabici (Greene et al., 1997); Denitrovibrio acetiphilus is a strict anaerobe which oxidizes acetate and has Geovibrio ferrireducens as its closest phylogenetic relative (Myhr \& Torsvik, 2000); and Marinobacter aquaeolei is a facultative, mesophilic acetate-oxidizer (Huu et al., 1999). Comparison of the almost-complete $16 \mathrm{~S}$ rDNA sequence of strain $4 \mathrm{BON}^{\mathrm{T}}$ (1529 nt) with sequences in the public databases indicated that the strain was related to a group of uncultured microorganisms (LaPara et al., 2000) (mean similarity of $98 \%$; data not shown). Nevertheless, the bacterial species phylogenetically most closely related to strain $4 \mathrm{BON}^{\mathrm{T}}$ is Hydrogenophilus thermoluteolus (Hayashi et al., 1999) (sequence similarity of $91 \cdot 8 \%$ ). Strain $4 \mathrm{BON}^{\mathrm{T}}$ differs from $H$. thermoluteolus by its inability to oxidize hydrogen and by having a lower DNA G $+\mathrm{C}$ content $(58.6 \mathrm{~mol} \%$ for strain $4 \mathrm{BON}^{\mathrm{T}}$ vs $63-65 \mathrm{~mol} \%$ for $H$. thermoluteolus). Because of its distinct phenotypic, genotypic and phylogenetic characteristics, it is proposed that strain $4 \mathrm{BON}^{\mathrm{T}}$ represents a novel species, Petrobacter succinatimandens, within a novel genus, Petrobacter, within the $\beta$-Proteobacteria.

\section{Description of Petrobacter gen. nov.}

Petrobacter (Pe.tro.bac'ter. Gr. fem. n. petra rock, stone; M.L. masc. n. bacter equivalent of Gr. neut. n. bakterion rod, staff; N.L. masc. n. Petrobacter the stone bacterium). 
Cells are straight rods. Gram-negative. Spores are not formed. Grow aerobically and anaerobically only with nitrate. Moderately thermophilic member of the domain Bacteria, class $\beta$-Proteobacteria. Organic acids serve as main substrates.

The type species is Petrobacter succinatimandens.

\section{Description of Petrobacter succinatimandens sp. nov.}

Petrobacter succinatimandens (suc.ci.na.ti.man'dens. N.L. n. succinatum succinate; L. part. adj. mandens eating, consuming; N.L. masc. adj. succinatimandens consuming succinate).

Cells are straight rods $(0 \cdot 3-0 \cdot 4 \times 2 \mu \mathrm{m})$, which occur singly or in pairs and possess one polar flagellum. Spores are not formed. Stains Gram-negative. Round colonies (1-2 mm diameter) develop in roll tubes after 1 week incubation at $50{ }^{\circ} \mathrm{C}$. Chemo-organotroph. Obligate aerobe. Oxidase- and catalase-positive. Moderately thermophilic. The optimum temperature for growth is $55^{\circ} \mathrm{C}$ at $\mathrm{pH} 7$; temperature range between 35 and $60^{\circ} \mathrm{C}$. The optimum $\mathrm{pH}$ for growth is $6 \cdot 9$; growth occurs between $\mathrm{pH} 5 \cdot 5$ and $8 \cdot 0$. Slightly halotolerant, growing in the presence of up to $3 \% \mathrm{NaCl}$, with an optimum at $0.5 \%$. Oxidizes fumarate, pyruvate, succinate, ethanol and yeast extract in the presence of oxygen or nitrate as terminal electron acceptor. The following compounds are not used in aerobiosis or in the presence of nitrate as terminal electron acceptor: acetate, butyrate, propionate, valerate, isovalerate, lactate, adipate, alanine, Lglutamate, proline, serine, valine, fructose, glucose, lactose, maltose, ribose, xylose, vanillate, benzoate, 4-hydroxybenzoate, 3-methylbenzoate, phenylacetate, 4 -aminobenzoate, benzaldehyde. Nitrate is reduced to nitrous oxide. Elemental sulfur, sulfate, thiosulfate and nitrite are not used as electron acceptors. Isolated from an Australian oil well.

The type strain is $4 \mathrm{BON}^{\mathrm{T}}\left(=\mathrm{DSM} 15512^{\mathrm{T}}=\mathrm{CIP} 107790^{\mathrm{T}}\right)$. The $\mathrm{G}+\mathrm{C}$ content of the DNA is $58.6 \mathrm{~mol} \%$ (HPLC).

\section{Acknowledgements}

The financial supports to M. Bonilla Salinas from 'Consejo Nacional de Ciencia y Tecnología' (CONACyT) and 'Société Française d'Exportation des Ressources Educatives' (SFERE) are acknowledged. Many thanks to P. Roger for improving the manuscript and to S. Pedaccini for technical assistance. The funding from the Australian Research Council to B. K. C. P. and B. O. is gratefully acknowledged.

\section{References}

Altschul, S. F., Madden, T. L., Schaffer, A. A., Zhang, J., Zhang, Z., Miller, W. \& Lipman, D. J. (1997). Gapped BLAST and PSI-BLAST: a new generation of protein database search programs. Nucleic Acids Res 25, 3389-3402.

Balch, W. E., Fox, G. E., Magrum, R. J., Woese, C. R. \& Wolfe, R. S. (1979). Methanogens: reevaluation of a unique biological group. Microbiol Rev 43, 260-296.
Benson, D. A., Boguski, M. S., Lipman, D. J., Ostell, J., Ouellette, B. F. F., Rapp, B. A. \& Wheeler, D. L. (1999). GenBank. Nucleic Acids Res 27, 12-17.

Cord-Ruwisch, R. (1985). A quick method for the determination of dissolved and precipitated sulfides in cultures of sulfate-reducing bacteria. J Microbiol Methods 4, 33-36.

Davydova-Charakhch'yan, I. A., Mileeva, A. N., Mityushina, L. L. \& Belyaev, S. S. (1992). Acetogenic bacteria from oil fields of Tataria and western Siberia. Microbiology (English translation of Mikrobiologiya) 61, 208-216.

Fardeau, M.-L., Cayol, J.-L., Magot, M. \& Ollivier, B. (1993). $\mathrm{H}_{2}$ oxidation in the presence of thiosulfate by a Thermoanaerobacter strain isolated from an oil-producing well. FEMS Microbiol Lett 113, 327-332.

Fardeau, M.-L., Ollivier, B., Patel, B. K. C., Magot, M., Thomas, P., Rimbault, A., Rocchiccioli, F. \& Garcia, J.-L. (1997). Thermotoga hypogea sp. nov., a xylanolytic, thermophilic bacterium from an oil-producing well. Int J Syst Bacteriol 47, 1013-1019.

Fardeau, M.-L., Magot, M., Patel, B. K. C., Thomas, P., Garcia, J.-L. \& Ollivier, B. (2000). Thermoanaerobacter subterraneus sp. nov., a novel thermophile isolated from oilfield water. Int $J$ Syst Evol Microbiol 50, 2141-2149.

Felsenstein, J. (1993). PHYLIP (phylogeny inference package), version 3.5c. Department of Genetics, University of Washington, Seattle, USA.

Gevertz, D., Telang, A. J., Voordouw, G. \& Jenneman, G. E. (2000). Isolation and characterization of strains $\mathrm{CVO}$ and FWKO $\mathrm{B}$, two novel nitrate-reducing, sulfide-oxidizing bacteria isolated from oil field brine. Appl Environ Microbiol 66, 2491-2501.

Grassia, G. S., McLean, K. M., Glénat, P., Bauld, J. \& Sheehy, A. J. (1996). A systematic survey for thermophilic fermentative bacteria and archaea in high temperature petroleum reservoirs. FEMS Microbiol Ecol 21, 47-58.

Greene, A. C., Patel, B. K. C. \& Sheehy, A. J. (1997). Deferribacter thermophilus gen. nov., sp. nov., a novel thermophilic manganeseand iron-reducing bacterium isolated from a petroleum reservoir. Int J Syst Bacteriol 47, 505-509.

Hall, T. A. (1999). BIOEDIT: a user-friendly biological sequence alignment editor and analysis program for Windows 95/98/NT. Nucleic Acids Symp Ser 41, 95-98.

Hayashi, N. R., Ishida, T., Yokota, A., Kodama, T. \& Igarashi, Y. (1999). Hydrogenophilus thermoluteolus gen. nov., sp. nov., a thermophilic, facultatively chemolithoautotrophic, hydrogen-oxidizing bacterium. Int J Syst Bacteriol 49, 783-786.

Hungate, R. E. (1969). A roll-tube method for the cultivation of strict anaerobes. Methods Microbiol 3B, 117-132.

Huu, N. B., Denner, E. B. M., Ha, D. T. C., Wanner, G. \& Stan-Lotter, H. (1999). Marinobacter aquaeolei sp. nov., a halophilic bacterium isolated from a Vietnamese oil-producing well. Int J Syst Bacteriol 49, 367-375.

Ivanov, M. V., Belayaev, S. S., Zyakun, A. M., Bondars, V. \& Laurinivicius, K. (1983). Microbiological methane formation in oil field development. Geokhimiya 11, 1647-1654.

Jukes, T. H. \& Cantor, C. R. (1969). Evolution of protein molecules. In Mammalian Protein Metabolism, pp. 21-132. Edited by H. N. Munro. New York: Academic Press.

Knapp, J. S. \& Clark, V. L. (1984). Anaerobic growth of Neisseria gonorrhoeae coupled to nitrite reduction. Infect Immun 46, 176-181.

Koussémon, M., Combet-Blanc, Y., Patel, B. K. C., Cayol, J.-L., Thomas, P., Garcia, J.-L. \& Ollivier, B. (2001). Propionibacterium microaerophilum sp. nov., a microaerophilic bacterium 
isolated from olive mill wastewater. Int J Syst Evol Microbiol 51, 1373-1382.

LaPara, T. M., Nakatsu, C. H., Pantea, L. \& Alleman, J. E. (2000). Phylogenetic analysis of bacterial communities in mesophilic and thermophilic bioreactors treating pharmaceutical wastewater. Appl Environ Microbiol 66, 3951-3959.

Magot, M., Ollivier, B. \& Patel, B. K. C. (2000). Microbiology of petroleum reservoirs. Antonie van Leeuwenhoek 77, 103-116.

Maidak, B. L., Cole, J. R., Lilburn, T. G. \& 7 other authors (2001). The RDP-II (Ribosomal Database Project). Nucleic Acids Res 29, 173-174.

Mesbah, M., Premachandran, U. \& Whitman, W. B. (1989). Precise measurement of the $\mathrm{G}+\mathrm{C}$ content of deoxyribonucleic acid by high-performance liquid chromatography. Int J Syst Bacteriol 39, 159-167.

Miranda-Tello, E., Fardeau, M. L., Fernandez, L., Ramirez, F., Cayol, J.-L., Thomas, P., Garcia, J.-L. \& Ollivier, B. (2003). Desulfovibrio capillatus sp. nov., a novel sulfate-reducing bacterium isolated from an oil field separator located in the Gulf of Mexico. Anaerobe 9, 97-103.

Mueller, R. F. \& Nielsen, P. H. (1996). Characterization of thermophilic consortia from two souring oil reservoirs. Appl Environ Microbiol 62, 3083-3087.

Myhr, S. \& Torsvik, T. (2000). Denitrovibrio acetiphilus, a novel genus and species of dissimilatory nitrate-reducing bacterium isolated from an oil reservoir model column. Int J Syst Evol Microbiol 50, 1611-1619.

Nilsen, R. K., Beeder, J., Thorstenson, T. \& Torsvik, T. (1996). Distribution of thermophilic marine sulfate reducers in North Sea oil field waters and oil reservoirs. Appl Environ Microbiol 62, 1793-1798.

Ollivier, B., Fardeau, M.-L., Cayol, J.-L., Magot, M., Patel, B. K. C., Prensier, G. \& Garcia, J.-L. (1998). Methanocalculus halotolerans gen. nov., sp. nov., isolated from an oil-producing well. Int J Syst Bacteriol 48, 821-828.

Rees, G. N., Patel, B. K. C., Grassia, G. S. \& Sheehy, A. J. (1997). Anaerobaculum thermoterrenum gen. nov., sp. nov., a novel, thermophilic bacterium which ferments citrate. Int J Syst Bacteriol 47, 150-154.

Saitou, N. \& Nei, M. (1987). The neighbor-joining method: a new method for reconstructing phylogenetic trees. Mol Biol Evol 4, 406-425.

Telang, A. J., Ebert, S., Foght, J. M., Westlake, D. W. S., Jenneman, G. E., Gevertz, D. \& Voordouw, G. (1997). Effect of nitrate injection on the microbial community in an oil field as monitored by reverse sample genome probing. Appl Environ Microbiol 63, 1785-1793.

Voordouw, G., Armstrong, S. M., Reimer, M. F., Fouts, B., Telang, A. J., Shen, Y. \& Gevertz, D. (1996). Characterization of 16S rRNA genes from oil field microbial communities indicates the presence of a variety of sulfate-reducing, fermentative, and sulfide-oxidizing bacteria. Appl Environ Microbiol 62, 1623-1629. 